\title{
Drawing Distinctions: What is Post-Critical Pedagogy?
}

\author{
Kai Wortmann (University of Tübingen)
}

\begin{abstract}
:
Post-critical pedagogy is an attempt to step outside the endless repetition of critical research in education. 'Posting' critique and thereby posing the question of alternatives works against a stagnating tendency for current educational debates to appear unsatisfactory, paralysing, and tedious. This essay describes the limits of critical pedagogy and possibilities of a 'post-critical pedagogy'. It is structured according to the term's three elements of 'critique', 'post', and 'pedagogy'. For each of these elements, the essay describes two ways of understanding; not to play them off against each other, but to show how manifold post-critical pedagogy can and should be. The essay concludes with a proposal of three analytical dimensions for further work on a post-critical pedagogy.
\end{abstract}

Keywords:

Bruno Latour; critique; critical pedagogy; postcritique; post-critical pedagogy

\section{Introduction}

Post-critical pedagogy is an attempt to step outside the endless repetition of critical research in education. 'Posting' critique and thereby posing the question of alternatives works against a stagnating tendency for current educational debates to appear unsatisfactory, paralysing, and tedious. This essay aims to describe the limits of critical pedagogy and to provide a taste of the elements that could comprise a post-critical pedagogy. The essay is structured according to the term's three elements, starting with 'critique', moving to 'post', and ending with 'pedagogy'. For each of these elements, I will offer two ways of understanding; not to play them off against each other, but to show how manifold post-critical pedagogy can and should be. I will conclude with a proposal of three analytical dimensions for further work on a post-critical pedagogy.

The term 'post-critical pedagogy' was coined by an exceptional text entitled Manifesto for a Post-Critical Pedagogy (Hodgson et al., 2017) that has generated a great deal of discussion about the question of what a post-critical pedagogy might look like. ${ }^{1}$ In only four pages, the authors 'made manifest' the feeling shared by many working in education that "the work of critical pedagogy....is largely done" (Hodgson et al., 2018, p. 18). This can be seen as a radical claim, especially when considering that "[f]or years, critical pedagogy (in some form) has been the dominant Western mode of educational thought and practice, and critical theory an orthodoxy in...educational research" (Hodgson et al., 2018, p. 8). The various 'forms' refer to educational thought drawing on the traditions of American Critical Pedagogy, the German Frankfurt School, and French poststructuralist theory. Surely, these positions differ between and even contradict each other, however their reception in education also has certain characteristics in common (two of which I will point out).

Hodgson et al. suggested, in line with Bruno Latour (2004), that "critique has run out of steam". Whereas the critical instruments and procedures once had been appropriate to achieve their aims they are not anymore. With this in mind, the fact that these incredibly influential traditions in educational research originated in times with socio-political challenges vastly different from our own makes it much less surprising that they need alterations and even radical changes. "The constitution of prejudice and structural inequality is different now than it was when such theories proposed radical contestation to the status quo and achieved huge shifts" (Hodgson et al., 2017, p. 80). To acknowledge these huge shifts as positive achievements of critical pedagogy is crucial for any post-critical perspective.

Therefore, I want to emphasize at the outset that postcritical pedagogy is not against critique. This can already be seen in the fact that post-critical pedagogy points out problems of critical pedagogy - and therefore is itself inevitably critical. However - and this is the crucial difference - post-critical pedagogy does not stop at pointing out problems, as one of the problems pointed at is precisely the tendency in educational debates only to problematize, to say what is wrong, what is bad, what needs to change and so forth. How to change and what to do instead are quite often out of focus. Consequently, postcritical pedagogy is committed to going beyond critique and to saying positively what is good and valuable in education, not only as a means to change or as the desirable changed state, but also to describe what is worthwhile to continue or maintain. Since this 'going beyond' must 
include 'passing through', one could even say that postcritical pedagogy is not only not against critique, but even that critique is a necessary part of post-critical pedagogy. We will come back to this.

\section{'Critical': Problems with Critique}

What are the problems with critique? In short, I am going to define two. The first I have just alluded to: the overly negative way of speaking. To say something 'critically' usually means to say how something should not be. Critical pedagogy operates in a negative "intellectual mood" (Felski, 2015, p. 3), investigating, for example, unjust social conditions, problematic modes of subjectivation, or deficient relations to oneself and the world that must be overcome. In this intellectual mood, objects are seen in an overly negative way; the act of seeing them, i.e., of doing critical research, is governed by a "stance of againstness, which is expressed in very different modes“, such as "in a digging down for hidden truths or a more ironic stance of 'troubling' or 'problematizing'” (Felski, 2015, p. 189). Whereas critical pedagogues often see themselves as scientific, objective, rational, and detached, Felski argued that "[c]ritical detachment is not an absence of mood, but one manifestation of it, casting a certain shadow over its object” (Felski, 2015, p. 21). This shadow, like any, allows certain aspects of the object to come to the fore and conceals others. This in itself is not problematic, but it becomes so at the very moment where the critical mood seems to have almost no alternative: In the present educational-scientific discourse, who does not want to be critical?

The second problem is slightly more technical. It refers to what Latour called the "debunking impetus" of critique (2004, p. 232). This style of doing research consists of debunking the hidden realities behind the surface of educational phenomena. Consider this example: a student is out of place in her school. A critical pedagogue's explanation for this phenomenon could be that it is because of her habitus. He might even add that since schools automatically reproduce a certain type of student no matter whether the teachers know about this, we cannot do much about it. Again, there is nothing inherently wrong with the concept of habitus, but this sort of application can easily become problematic. First, it can lead to reducing the phenomenon to its critical explanation. If one - almost automatically, because of one's critical training - thinks that what is 'really' going on in every such case can only be some type of critically identified structure, e.g., a misfit between habitus and social field, one might become less inclined to look for aspects of the phenomenon that go against this interpretation but that might equally be part of 'reality' (e.g., ambivalences, divergences, or resistances). Therefore, although the critical idea of the habitus is an addition to reality, it can easily lead to subtractions and alltoo-easily to ready-made limitations of perception.
Moreover, there is a second problem with the debunking style of critique, which is that it can lead to sheer hopelessness. Probably most of us who passionately teach Bourdieu (or other critical thinkers) to students have experienced a certain type of desperate reaction, along the lines of 'whatever I will do, unknowingly I will reproduce the inequalities of society and therefore my actions will make no difference'. On the one hand, this of course is not Bourdieu's position, but on the other hand, this feeling of being paralysed is not at all unreasonable, for it originates in the conviction easily and often plausibly acquired when reading critical pedagogy that there is always a larger force (e.g., society), a deeper power (e.g., racism) or an invisible hand (e.g., habitus) at work to which oneself as a teacher is nothing but subjected to.

\section{'Post-': How to Relate to the Critical}

Surely, 'post' in 'post-critical pedagogy' implies a difference between itself and the 'posted' critique. In order not only to declare this difference but also really show in what it consists, 'post' raises the question of the relation between the two. I want to suggest that there is no single answer to this question. Instead, I will show how one could adjust the meaning of 'post' according to different aspects or understandings of critique.

'Post' can be defined as 'progress', which in turn can be understood in different categories. For example, it can be understood simply as progression of time - as, for example, in 'postmodern' - which applied to post-critical pedagogy would mean that there was a period of critical pedagogy that now has come to an end. 'Post' can also be understood as a progress more closely connected to the subject matter - as, for example, in 'poststructuralist' which implies there was a certain characteristic that has been overcome. Most commonly, the usage of 'post' refers to both the time and the subject matter. This is also the case in Latour's claim that critique 'has run out of steam'. The debunking style of critique (characteristic) is not appropriate anymore (time); accordingly, Latour suggested that one should turn away from it. In this sense of 'critique' as debunking activity, post-critical pedagogy can be seen as a project that tries to take the next step after it has become clear that critical pedagogy has run out of steam.

However, there are other understandings of critique in which such 'either-or' decisions between critique and its 'posting' cannot be made that easily, since both elements are mutually - and maybe even dialectically - dependent upon each other. This is, for instance, the case in the distinction between positivity and negativity as in the first sense of critique: a 'purely positive' way of speaking would neither be possible nor desirable. Concerning an understanding of critique as an overly negative way of speaking, it makes little sense to say "[l]et the critical inquiries go on; we are just looking for other strategies" (Hodgson et al., 2017, p. 81). Still, “other strategies” refers to a difference between two options of which one must 
decide. This decision seems exceedingly difficult because of the mutual dependence between positive and negative ways of speaking. Vlieghe and Zamojski indeed make the difficult theoretical operation "to conceive of life in a purely [emphasis added] positive way” (2019, p. 76). In contrast, I argued that critical pedagogy suffers from an overly negative way of speaking, which allows post-critical pedagogy to emphasize positivity a little more and negativity a little less, but still leaves room for negativity (Wortmann, 2019). For this more gradual way of conceptualizing the relation between 'posted' negativity and 'posting' positivity, I find the image of a pendulum helpful: it is 'stuck' in one side (prevailing negativity) and by accentuating the other side (positivity), it can be encouraged to swing again. This seems to be a muchneeded move in today's educational research to which post-critical pedagogy can contribute.

\section{'Pedagogy’: Practices and Research}

'Pedagogy' inherits a double meaning, referring to both pedagogical practices and scientific discourse about those practices.

The first was discussed mainly in Vlieghe and Zamojski's book Towards an Ontology of Teaching: Thing-centred Pedagogy, Affirmation and Love for the World (2019). It conceptualized teaching as an activity that presupposes an affirmative attitude towards the subject matter since teaching consists mainly of passing on one's love for the world to a new generation. Educational practices are concerned with a thing, an object of study, rather than with the educated individuals. Accordingly, the authority in education lies neither in the teacher nor in the students, but in the thing. It is the thing that has the power to equalize the students. The task of the teacher therefore is to make the students attentive to the subject matter to which - so assumed following Rancière - they all can relate equally. Already in this short sketch one can clearly see many differences between critical and post-critical pedagogy. Whereas critical pedagogy often would focus primarily on the different backgrounds of the students, post-critical pedagogy starts from the assumption of radical equality. Or, whereas critical pedagogy conceives of education as a means to socio-political ends, post-critical pedagogy sees education as activity for its own sake.

Most of the contributions to post-critical pedagogy have, however, discussed it as a way of doing educational research. This opens the question of what types of research 'post-critical pedagogy' refers to and to which specific debates it reacts. First, one must take into account that postcritical pedagogy responds to educational research in the English-speaking discourse. Most probably, in other contexts the state of discussion would demand quite different interventions. Second, there is the question of size of the sub-disciplinary scope of post-critical pedagogy. Is it an 'educational theory'? Or does it diagnose tendencies also in empirical research? For one might wonder whether the described problems of critical pedagogy are at all prevalent in today's empirical educational research. And indeed, a large part of our discipline is not very critical in the sense of a prevailing negative mood. Quite contrary, much research - unfortunately often quantitative - operates with ongoing promises of technocratic positivity: it pretends to know and continues to offer easy solutions for almost every question of educational policy and practice. Against this type of power-phantasmatic research, postcritical pedagogy could pose the question of how to speak positively and affirmatively without offering easy answers.

\section{Outlook}

So far, I have sketched out two possible understandings for each of the three elements of the term 'post-critical pedagogy’. In summary, 'critique’ can be conceptualized as debunking activity or negative way of speaking, 'post-' can refer to progress or a new emphasis, and 'pedagogy' can mean pedagogical practice or research. Surely, one could have made further and more fine-grained distinctions. ${ }^{2}$ However, the aim of this essay is not to provide a comprehensive overview, but to introduce questions emerging from the issue and offer some indicative answers. Finally, I want to provide an outlook by suggesting three broad analytical dimensions for further work on a post-critical pedagogy. ${ }^{3}$

The first dimension is descriptive: what does criticism as a mode of educational research or theory-building look like? What rhetorical movements and figures are used and what conceptual assumptions and methodical procedures do they imply? By answering these questions, one could conceive of critical pedagogy as a "specific set of...conventions, expectations and orientations" with "distinctive aesthetic, affective, and analytical components” (Anker \& Felski, 2017, p. 1, 3).

The second dimension is evaluative: what problems does this critical mode carry with it? To answer this question, it seems promising to acknowledge the fruitful aspects of the critical perspective, but also to expect that, like any, it has specific blind spots that can be named and traced back to its conceptual preconditions and methodological obligations. These blind spots can be identified accordingly: what aspects of pedagogical interactions does criticism focus on and which aspects are necessarily out of its scope? That is, where are the limits of what can be described with critical terminology?

The third dimension is exploratory: what alternative perspectives can be identified and developed in order to take into account these other (aspects of) things in another way? What other ways of speaking would be available to theory-building and what other methods would be possible for empirical educational research that neither repeat the problems of critical pedagogy nor give up its achievements? What methodological orientations do they offer? 
From answers to these questions, one can derive both the description and justification of alternatives that extend or shift the boundaries of critical pedagogy. The value of a post-critical perspective could thus consist of being able to take into account other (aspects of) educational things in another way and thereby multiply contemporary educational debates. ${ }^{4}$

\section{References}

Anker, E. S., \& Felski, R. (2017). Introduction. In E. S. Anker, \& R. Felski (Eds.), Critique and postcritique (pp. 1-28). Duke University Press.

Ellsworth, E. (1989). Why doesn't this feel empowering? Working through the repressive myths of critical pedagogy. Harvard Educational Review, 59(3), 297-324.

Felski, R. (2015). The limits of critique. University of Chicago Press.

Friesen, N. (2017). Towards a pedagogical hermeneutics: A response to the 'manifesto for a post-critical pedagogy'. In N. Hodgson, J. Vlieghe, \& P. Zamojski (Eds.), Manifesto for a post-critical pedagogy (pp. 43-48). punctum books.

Hodgson, N., Vlieghe, J., \& Zamojski, P. (2017). Manifesto for a post-critical pedagogy. punctum books.

Hodgson, N., Vlieghe, J., \& Zamojski, P. (2018). Education and the love for the world: Articulating a post-critical educational philosophy. Foro de Educación, 16(24), 7-20. https://doi.org/10.14516/fde.576

Hodgson, N., Vlieghe, J., \& Zamojski, P. (2020a). Manifestations of the post-critical: From shared principles to new pedagogical paths. Teoría de la Educación, 32(2), 13-23. http://dx.doi.org/10.14201/teri.22576

Hodgson, N., Vlieghe, J., \& Zamojski, P. (Eds.) (2020b). Post-critical perspectives on higher education: Reclaiming the educational in the university. Springer. https://doi.org/10.1007/978-3-030-45019-9

Latour, B. (2004). Why has critique run out of steam? From matters of fact to matters of concern. Critical Inquiry, 30(2), 225-248.

Latour, B. (2019). Against critique, for critique. In I. Graw, \& C. Menke (Eds.), The value of critique: Exploring the interrelations of value, critique, and artistic labour (pp. 15-30). Campus.

Masschelein, J. (2004). How to conceive of critical educational theory today? Journal of Philosophy of Education, 38(3), 351-367. https://doi.org/10.1111/j.0309-8249.2004.00390.x

Oliverio, S. (2019). An edifying philosophy of education? Starting a conversation between Rorty and post-critical pedagogy. Ethics and Education, 14(4), 482-496. https://doi.org/10.1080/17449642.2019.1669311

Oliverio, S. (2020). The question of a thing-centred view of education: Notes on Vlieghe and Zamojski’s towards an ontology of teaching. Studies in Philosophy and Education, 39(1), 103-107. https://doi.org/10.1080/17449642.2019.1669311

Rieger-Ladich, M. (in press). Abstieg vom Feldherrenhügel. Konturen einer neuen Praxis der Kritik. In M. Harant, U. Küchler, \& P. Thomas (Eds.), Theorien! Horizonte für die Lehrerbildung. Tübingen University Press.

Schildermans, H. (2020). On swimming and sweaters. A response to Vlieghe and Zamojski's towards an ontology of teaching. Studies in Philosophy and Education, 39(1), 109-112. https://doi.org/10.1007/s11217-019-09695-8

Schwimmer, M. (2019). Rorty, post-critical pedagogy and hope: A response. Ethics and Education, 14(4), 497-504. https://doi.org/10.1080/17449642.2019.1669355

Thoilliez, B. (2019). Pedagogical hope and education beyond critique: Towards pedagogy with a lower case 'p'. Ethics and Education, 14(4), 453-466. https://doi.org/10.1080/17449642.2019.1669379

Thompson, C. (2004). Diesseits von Authentizität und Emanzipation. Verschiebungen kritischer Erziehungswissenschaft zu einer 'kritischen Ontologie der Gegenwart'. In N. Ricken, \& M. Rieger-Ladich (Eds.), Michel Foucault: Pädagogische Lektüren (pp. 39-56). VS Verlag für Sozialwissenschaften.

Vlieghe, J., \& Zamojski, P. (2017). The event, the messianic and the affirmation of life. A post-critical perspective on education with Agamben and Badiou. Policy Futures in Education, 15(7), 849-860. https://doi.org/10.1177/1478210317706621

Vlieghe, J., \& Zamojski, P. (2019). Towards an ontology of teaching: Thing-centred pedagogy, affirmation and love for the world. Springer. https://doi.org/10.1007/978-3-030-16003-6 
Vlieghe, J., \& Zamojski, P. (2020). Taking up the threads: The aesthetic, temporal, and political dimensions of teaching. Studies in Philosophy and Education, 39(1), 113-117. https://doi.org/10.1007/s11217-019-09694-9

Wortmann, K. (2019). Post-critical pedagogy as poetic practice: Combining affirmative and critical vocabularies. Ethics and Education, 14(4), 467-481. https://doi.org/10.1080/17449642.2019.1669942

Wortmann, K. (in press). Abwenden, Verwinden, Einfalten: Über die Vergeblichkeit des Versuchs, nicht mehr kritisch zu sein. In M. Karcher, \& S. Rödel (Eds.), Lebendige Theorie. Textem.

\section{Recommended Citation}

Wortmann, K. (2020). Drawing distinctions: What is post-critical pedagogy? On Education. Journal for Research and Debate, 3(9). https://doi.org/10.17899/on_ed.2020.9.1

\section{About the Author}

Kai Wortmann, MSc, is a philosopher of education with a strong interest in innovative empirical research. His research focuses on contemporary pragmatist educational theory, critique in pedagogy, and empirical research methodologies. He is a $\mathrm{PhD}$ candidate at the Institute of Education, University of Tübingen.

\footnotetext{
${ }^{1}$ This essay cannot provide a comprehensive overview of the ongoing debate. For contributions explicitly referring to 'post-critical pedagogy' see, e.g., Hodgson et al., 2017, 2018, 2020a, 2020b; Friesen, 2017; Oliverio, 2019, 2020; Schildermans, 2020; Schwimmer, 2019; Thoilliez, 2019; Vlieghe \& Zamojski, 2017, 2019, 2020; Wortmann, 2019, in press. The need to rethink critique in pedagogy was of course also expressed before or without referring to the term (see, e.g., Ellsworth, 1989; Masschelein, 2004; Rieger-Ladich, in press; Thompson, 2004).

${ }^{2}$ Latour himself recently distinguished four different forms of critique (2019); interestingly, the “debunking impetus” he described 15 years earlier is not one of them.

${ }^{3}$ These three dimensions can be divided analytically only, since although they can be presented separately, their answers will be intricately linked and often converge. Note, for example, how I presented the problems of critique through a description of what critique can mean, which is a mix of the descriptive and evaluative dimension.

${ }^{4}$ I want to thank Joris Vlieghe and Piotr Zamojski for making me see new aspects of education in a new way, Anne Rohstock for trusting me to contributing the opening essay for this issue, and Stefano Oliverio and Max Möhring for their helpful comments on the text.
} 